\title{
Global review of policies \& guidelines for recycling of solar PV modules
}

\author{
Arvind Sharma ${ }^{\mathrm{a}, \mathrm{b}}$, Suneel Pandey ${ }^{\mathrm{b}}$, Mohan Kolhe \\ ${ }^{a}$ Faculty of Engineering and Science, University of Agder. P.O. Box 422, NO 4604, Kristiansand, Norway \\ ${ }^{b}$ The Energy and Resources Institute (TERI), New Delhi - 110 003, India
}

\begin{abstract}
An early development of PV recycling industry will be essential for use renewable energy in a sustainable manner. It has been estimated that the cumulative PV waste has reached 43,500-250,000 metric tonnes in 2016 , is $0.1 \%-0.6 \%$ of the total installed PV capacity (4 million metric tonnes). The percentage of the solar PV waste will increase further and will contribute $4 \%$ of the installed PV capacity by 2030s. However, there are unique opportunities for creating economic value from the PV waste (e.g. recovery of raw material, market for new PV recycle industries etc). This paper has reviewed policies and guidelines for PV recycling in selected countries (i.e. Germany, UK, Italy, Switzerland, Norway, Czech Republic, Japan, USA, China, South Korea, India). PV systems are increasing exponentially in India and China, therefore end-of-life management policies regulations are required to support the transition to sustainable PV life cycle programme. The EU member states have taken initiatives for establishing the regime for PV module collection and handling in accordance with Waste Electrical and Electronic Equipment Directive (WEEE Directive) and has been discussed for implementation in addition to the existing policies. PV manufacturers have also developed voluntarily few models for PV recycling: First Solar, SolarWorld Global and PV Cycle. First Solar's industry-leading recycling services enable PV power plant and module owners to meet their module end-of-life (EOL) obligation simply, cost-effectively and responsibly. SolarWorld program is designed to recycle PV modules that have undergone any type of damage (e.g. glass breakage, defective laminate or electrical faults) and as a result SolarWorld was ranked first overall among crystalline PV manufacturers in a report by the Silicon Valley Toxic Coalition. PV Cycle is a program that was created by the European PV manufacturing industries and it is sustained to retain its world-leading position in the collection and treatment of photovoltaic module waste. Based on the specific national conditions and relative PV sector maturity, the enabling framework should focus on adopting a system-level approach. It has been critically observed that the development regulatory framework/guidelines and innovative business models, build up capacity of local institutions and PV recycling industry are very important for the PV end-of-life management system. Some of the countries which are early at stage of addressing PV recycling challenges, can use the EU's expertise as well as in coordination with the PV manufacturers for developing regulatory framework and guidelines.
\end{abstract}

Keywords: Photovoltaic recycling, $P V$ life cycle programs, $P V$ end-of-life, $P V$ recycling policing and guidelines.

\section{Introduction}

To ensure a secure, affordable, environmentally clean and sustainable source of energy, many countries are pushing towards the deployment of renewable energy sources. Among numerous environment friendly renewable energy sources, solar PV based system is one of the fastest growing clean energy technology, due to its drastic reduction in capital costs as well as technological advancements [1]. It has been reported that the price of solar PV system has decreased by 50\% since 2010, leading to deployment of solar PV technologies for clean electrical energy productions [2, 3]. It is expected that solar energy will contribute substantially in the energy mix and going to become one of the main clean energy sources in the future. The growth of solar PV has grown-up rapidly and the cumulative global installed PV capacity has reached to $397.4 \mathrm{GW}$ in 2017 [4]. According to the data available from Solar

\footnotetext{
* Manuscript received November 18, 2018; revised July 17, 2019.

Corresponding author. E-mail address: arvind.sharma@uia.no, spandey@teri.res.in, mohan.1.kolhe@uia.no doi: $10.12720 /$ sgce.8.5.597-610
} 
Power Europe, new solar PV capacity of $98.9 \mathrm{GW}$ has been added in 2017, has a growth of 29.3\% compare to 2016. The solar PV power demand globally has risen-up from $1 \mathrm{GW}$ in 2004 to $397.4 \mathrm{GW}$ in 2017 [4]. It shows around 30\% annual growth rate, higher than any other emerging renewable energybased technologies [5].

According to Bridge to India report on the Indian solar market, the total solar installed capacity has reached to 19,516 MW in Dec 2017. The major contributions on this installed capacity are from utilityscale PV of 17,415 MW (89\%), and rooftop PV capacity of 2,101 MW (11\%). The report also forecasts that India will become the second biggest market after China in years 2018 and expect to install $11 \mathrm{GW}$ in India this year, whereas the U.S. should install $10 \mathrm{GW}$ and will become third biggest market after India. Due to large-scale deployment of solar PV in China, it is expected to have 53 and $60 \mathrm{GW}$ of Solar PV installation (around 47\% market share) in 2018 [6, 7].

Although, we understand that the solar PV is a clean source of energy and environmentally friendly technology but like any other technology it ages and degrades with time. It is expected the silicone based solar PV modules' life time is around 20-25 years and after that it ultimately requires decommissioning of PV modules and proper recycling and disposal of the system components. As the number of solar PV installation are growing globally, it needs special attention and involvement from industries, policy makers, stakeholders at each step of the product life-cycle. Generally, it is recommended to use sustainable waste management concept that offers opportunities to reduce, reuse, and recycle. With the large anticipation of PV waste, the recycling of PV module has become a main research area for developing new technologies for material recovery as well as developing appropriate regulations / guidelines / policies.

This article is reviewing policies, regulatory framework and life cycle management techniques for implementation of implementation of PV waste recycling in selected countries (i.e. Germany, UK, Italy, Switzerland, Norway, Czech Republic, Japan, USA, China, South Korea, India). Also, some of the initiatives (i.e. First Solar, SolarWorld Global and PV Cycle) taken by PV manufacturers for recycling has been studied. This study will help to provide learning and best practices from selected countries to enhance knowledge, capacity building with technological and regulatory systems dealing with PV module waste and recycling.

\section{Solar PV Module Waste Projection}

\subsection{Overview}

It has been reported that the total annual of e-waste in the world was 41.8 million in 2016. However, annual PV module waste accounts for 2,50,000 $\mathrm{t}$ in 2016, represents only $0.6 \%$ of total e-waste [8]. But the contribution of global waste from PV module will be going to rise significantly in the coming years. In ref [9], IRENA and IEA have projected the current and future trends of PV waste generation based on global PV growth rates and IRENA's RE roadmap is used for forecasting PV waste till 20130, whereas IEA's Technology Roadmap on Solar Photovoltaic Energy (IEA, 2014) for forecasting PV waste from 2030 to 2050. In these reports, the regular loss and early loss scenarios are considered for analysis purpose. The early-loss scenario includes failures requiring of PV module such as broken glasses, cells cracking in back-sheets, etc. However, only PV module with safety failure is considered for replacement, and other defects such as power output loss or module dis-coloration are ignored. In regular scenario, neither initial losses nor early losses are considered.

According to the ref [8], in the regular-loss scenario, waste generation from solar PV module will reach to 1.7 million t by 2030 and it will rise further and may reach approximately 60 million t by 2050 . In case of early-loss scenario, a huge amount of PV waste will be generated during 2030-50 compare to previous case. The total PV waste generation will be 8 million $\mathrm{t}$ in 2030 and 78 million $\mathrm{t}$ in 2050. This difference may be due to high percentage of PV module failure has been considered in the early-loss scenario compare to the regular-loss scenario and future PV module waste generation will be between the both scenarios (i.e. early loss and regular loss) projections. 


\subsection{Solar PV module waste projection's scenario until 2030}

PV module waste projections for selected countries are reported based on early case scenarios and regular case scenarios (respectively until 2030 and 2030-2050) in ref [9]. It has been observed that the highest expected PV module waste will be generated mainly from Asia, Europe and North America. However, Asia alone will contribute to 3.5 million t of PV module waste followed by Europe and North America, 2 million $t$ and 1.1 million $t$ respectively. According to the future projection among the three Asian countries (i.e. China, India and Japan), the installed solar PV capacity in China will be the highest around $420 \mathrm{GW}$ by 2030 and China will generate maximum 0.2 to 1.5 million t solar PV module waste, whereas Japan and India will follow to China and will accumulate 0.20 to 1 million t, and $0.50-0.30$ million $\mathrm{t}$ of PV waste respectively [9].

In Europe, Germany will contribute maximum share of $75 \mathrm{GW}$ solar PV by 2030 and it is predicted that 0.40 to 1 million $\mathrm{t}$ of PV module waste will be accumulated. Other European countries such as Italy and France, will make significant contribution in solar PV waste in the future.

In North America, the US will be the prime contributor for PV module waste between 0.17 to 1 million $\mathrm{t}$ by 2030 and will have total installed solar PV capacity of around $240 \mathrm{GW}$ till that year. Other countries in North America such as Canada and Mexico will also have contribution of 0.08 and 0.03 million $\mathrm{t}$ by 2030.

Africa and Latin America will also see increasing PV module waste generation. South Africa (PV waste $-8.5-80 \mathrm{~K}$ t by 2030) and Brazil (PV waste $2.5-8.5 \mathrm{~K}$, $\mathrm{t}$ by 2030 ) will be the main contributors in PV waste. Other significant PV module waste markets by 2030 will include the Republic of South Korea with cumulative PV waste of $25-150 \mathrm{~K}$ t and Australia with $30-145 \mathrm{~K}$ t.

\subsection{Waste volume surge in $2030-2050$}

As discussed in the previous section 2.2 for 2030 scenario for PV waste, China, Germany and Japan are the top three countries which will create maximum solar PV module waste. It is predicted that China will take the lead due to its large-scale solar PV deployment programme and will generate maximum solar PV waste of 13.5-20 million $t$ by 2050. Japan will maintain its position 3 with $6.5-7.5$ million $t$ of PV waste generation, followed by India (4.4-7.5 million t) and Germany (4.3 million t) [9].

Based on the projected PV waste, it is obvious that there are enormous opportunities for setting up new PV recycling industries across the globe. So far there are few industries, who have competence and expertise to setup PV recycling plant(s). French water and waste group Veolia has operationalized Europe's first recycling plant for solar PV module. The company has a contract with solar industry recycling organization PV Cycle France to recycle 1,300 tonnes of solar panels in 2018 [10]. Recently, a German company, Geltz Umwelt-Technologies, has developed an advanced recycling plant, to recover up to $95 \%$ of the Si materials from the PV module [11] and the company is developing a pilot PV recycling facility with the EU's Horizon 2020 funding that could recycle up to 50,000 silicon-based PV modules per year. According to the PV recycling waste projections till 2030 and 2050 scenario, there should have many PV recycling industries in place to tackle the large amount of PV module waste across the globe.

\section{PV Waste Management Regulation in Different Countries}

As explained in the previous section that PV waste potential is going to rise rapidly after 2030 and more new countries will be planning to establish PV recycling industries for safe collection and recycling of PV module. It is essential to have stakeholder's involvement with every step of the PV system life cycle. Therefore, adequate policies and guidelines / regulations should be implemented with efficient processes for PV module end-of-life treatment. Regulatory frameworks should include the development of life cycle management techniques and recycling technologies for material recovery. In this section current approaches to PV waste management in different countries are reviewed. It begins with an overview of how today's most comprehensive end-of-life PV regulation i.e. the EU WEEE Directive. WEEE is applied in selected EU member states, including Germany and the UK. PV module waste 
management approaches are also outlined for Japan and the US. It also includes case studies of China and India, two of the most important growing PV markets.

\subsection{EU's Waste Electrical and Electronic Equipment Directive (WEEE Directive)}

EU has set up one of the main regulatory frameworks based on WEEE directives to address electrical and electronics waste. The objective of this framework is to effectively addresses the electrical and electronics waste generation in the $28 \mathrm{EU}$ member states and define certain level of responsibilities among different stakeholders [12]. According to the WEEE directives all electrical or electronic product manufacturers are legally accountable for proper waste management of the product no matter where manufacturing facility is located. The WEEE directive has detailed guidelines that includes collection, recovery, recycling along with environment and public health safety[13].

The first WEEE directive has come into force in 2003, but it didn't have adequate provision to tackle the large scale and diverse waste stream of PV module waste. In 2012, following a proposal by the EU Commission, the directive was further modified for end-of-life management of PV module. However, this modified WEEE Directive come into force on 13 August 2012, and EU members states has started in implementing new legal framework for PV module waste.

Currently, all the $28 \mathrm{EU}$ member states have taken initiatives for establishing the regime for PV module collection and handling in accordance with the directive (European Parliament and Council, 2012). According to the latest WEEE Directive PV manufacturers have main liability for the costs of collection, handling and treatment. However, they must satisfy a certain number of requirements and responsibilities as stated in the WEEE directive.

\subsection{Germany's national regulation}

Although, EU WEEE Directive was come into force in Germany on October 2015, through a modification of the Electrical and Electronic Equipment Act, but the utmost important part of the directive was to provide financial support, create collection and recovery of PV waste for proper recycling of the enormous amounts of historic installed capacity in Germany [14]. There are two financial mechanism or instruments defined by the Germany government for implementing the PV module recycling programme, are as follows.

\section{(i) Business-to-consumer (B2C) transactions}

According to the $\mathrm{B} 2 \mathrm{C}$ transaction, the new producers (e.g. A, B, C, D and E) will responsible for selling their product to the private households and will ensure present and future end-of-life obligations. This approach is very useful for private market or individual customers, who are willing to install PV module on their premises / houses. The B2C transaction approach is established based on the learning and experience from the earlier accredited producer compliance schemes. A basic concept of B2C transaction has shown in Figure1.

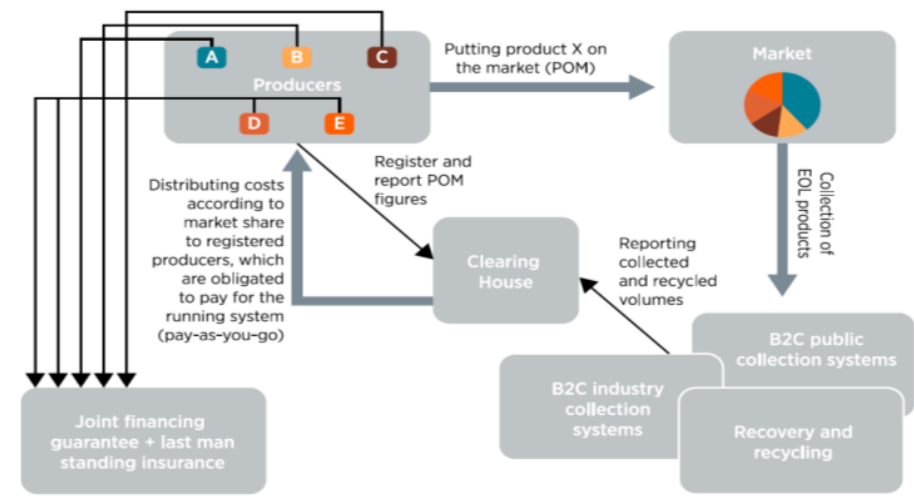

Fig. 1. B2C transaction mechanism for recycling of PV module [8] 
In the $\mathrm{B} 2 \mathrm{C}$ scenario two levels of processes are established for financing and to ensure collective producer compliance, are the following:

- Level 1 defines the cost related to collection system operation and instantaneous collection and recycling of PV waste products (i.e. old PV installation before being included in the scope of the law).

- Level 2 covers the enough financing mechanism for future collection and recycling of PV module which are going to be installed today or after inclusion into the scope of the law. The costs making mechanism is uniform for the PV module of Level 2 financing. This calculation is done considering the regulator, average lifetime of PV module, centralized return collection at municipal's end, and the handling and logistic costs.

PAYG (Pay as you go) system is widely in practice to cover Level 1 costs for all market stakeholders who placed their products of a certain category (e.g. PV module) on the market under B2C category. Another key requirement for producers is to register with a clearing house before they introduced their products into the market. It is very important for producers to cover Level 2 costs through a valid legal agreement then only clearing house gives e-waste registration number to the producers that must be printed on the product and bills.

In both cases, costs for collecting and recycling for all the PV waste will be distributed among all registered market stakeholders according to the waste volume collected. In case, a producer reveals that it collected and recycled its portion individually, those volumes will be subtracted from the outstanding fraction. In any situations, if a producer leaves the market, its market portion will be taken up by the others along with the accountability for financing collection and recycling.

(ii) Business-to-Business (B2B) transactions

B2B transaction approach provides a different financial model of end-of-life PV obligations for PV producers based on quantities, capacity size, level of complexity etc. In this approach, PV module handing and recycling seem to be more effective and organized if the final equipment or installation owner delivers for it. Still there is an option between the predetermined partners to agree on end-of-life responsibilities as described by the WEEE Directive either by contracting the PV producer to handle and recycle or create competitive market bids. Another benefit of this approach for PV producers is to have flexibility for selecting financing mechanism.

In case of large-scale PV plants, B2B transactions will most likely result in economic models that create capitals for collection and recycling from near-commercial end-of-life project cash flows. Subsequently, very profitable financing will be provided that allows previously agreed end-of-life obligations to be covered by contractual partners.

For B2C scenario, a producer has a choice to select either an individual for collection and recycling system or join a group of organizations, where as in B2B scenario PV module handing and recycling can become more effective and organized, if the final equipment or installation owner delivers for it. It can be concluded the B2C scenario is useful for individual household level for small scale application, whereas B2B scenario is applicable for largescale power plant.

\subsection{UK's regulatory and non-regulatory frameworks}

In the European Union, Britain UK was the first country to officially accept the EU's WEEE directive on PV components processing. According to the British policy regulations, which came into force on January 1, 2014, made it necessary for all PV module manufactures to share all the important data related to the PV module, such as the number PV module produced or imported, and their delivery network channels and they also should have a registered product conformity plan. Before WEEE directive came into force, UK also started voluntary produce initiatives (e.g. PV CYCLE) for recycling the PV modules. Due to the limited solar PV capacity installed before 2014, most end-of life PV modules would have been covered under warranties and returned through the B2B channel.

The UK has developed some specific guidelines, when it comes to a PV module producer and hence 
the extended producer-responsibility, when transferring the WEEE Directive into national law. According to the UK WEEE legislation, all PV producers must register under a producer compliance scheme and submit related data on products intended for household (B2C) and non-household (B2B) markets.

However, when it comes to financial support for B2C and B2B sales, the UK WEEE legislation contains minimum requirements that makes it differ from the EU WEEE Directive.

- PV producers are obliged to finance the collection of household PV module based on the market share. For example, a PV producer introducing $10 \%$ (by weight) of new PV modules into the UK market in any given year and pays for the collection and recycling of $10 \%$ of end-of life PV module collected in that year. The year when they were first introduced on the market will be ignored.

- PV producers must finance the handling and recycling of non-household (B2B) PV modules carrying the wheelie bin symbol and old modules without symbol will be exchanged by new ones.

In addition to the producer compliance scheme, the UK WEEE legislation has announced a new requirement for PV module installers to become member of a distributor takeback scheme. The UK now has quite a lot of producer compliance schemes and supplier take-back schemes that offer their services for very similar fees (UK Environment Agency, 2015).

The UK's WEEE legislation needs first-level treatment of PV module, which includes the registration of collected PV waste, to take place within the UK. Further treatment will most likely happen out of the country, since the economies of scale would not currently allow dedicated PV recycling facilities in the UK. However, in Germany registration is not mandatory but PV producers have flexibility to use appropriate financial model e.g. PAYG for payment collection.

\subsection{Italy's regulatory and non-regulatory frameworks}

Although in July 2005, WEEE Directive came into force in the Italian e-waste collection system but due to lack of financial mechanism in place and clear regulation that was not taken forward aggressively. Also, there was no legal single organization present for monitoring the working operation of the system. This leads to an inefficient coordination among different stakeholders for collection and recycling of PV module. In Italy, discussion on WEEE directive and its implementation were late compare to Germany, therefore Italy has a little amount of history data in this principle and limited practical experience [15].

In April 2014, Italy became the first major PV market player for adapting EU WEEE Directive (2012/29/EU) into its own national policy guidelines. This directive legislation was based on the extended producer responsibility (EPR) basic principle and held the PV module manufacturers financially accountable for the transport and recycling of PV across the country. In this directive, Solar PV was defined as WEEE for the first time, which also required all PV module manufacturers to join a National Register. The basic objective of a producer to become a Nation Register Member to provide the financing of the WEEE handling system and compliance. In order to ensure that directive is meeting the compliance, the respective organization (i.e. Decree in Italy) kept a certain part of the government supplied Feed-inTariff, to cover the proper collection, disposal and recycling of the panels. This held amount will only be repaid if the PV module manufactures can prove the PV module were properly disposed in a sound manner within 6 months of it being collected (Legislation No. 49, March 2014) [16].

Compare with Germany and UK, financial mechanism for collection, handling and treatment is different in Italy. Solar PV manufacturers are legally bound to get their money for safe and efficient recycling of PV module otherwise they will not get their money back from third party.

\subsection{Switzerland's regulatory and non-regulatory frameworks}

In Switzerland, PV module installed capacity was $1.4 \mathrm{GW}$ in the year 2015 (around $2.5 \%$ of the total electricity demand). The Switzerland government has made a lot of efforts to provide financial support such as subsidy with focus on the residential sector, which has already resulted in $20 \%$ growth in PV 
capacity in the year 2014 itself. The rapid growth of solar PV brings an important attention before the Switzerland' Government to address PV module waste in proper manner [16].

Before the WEEE Directive came into force existence, Government of Switzerland had established SENS foundation in 1991, which was responsible to take in 'white goods' such as washing machines, refrigerators, ovens, etc., various systems [17]. At the end of 2014, SENS and SWICO RECYCLYING made a commitment for adhering to the European Standards for WEEE collection, logistics and safe disposal through EN 50625 mandatory. SWICO RECYCLING has been set up under the Swiss Industrial Association Swico that provide the financial support for recycling of old equipment. PV module waste has included in this category for collection, handling and guaranteed safe disposal. Before 2015, PV module waste collection was only possible through on email or fax by the submitter to SENS.

SENS has made significant efforts to create awareness among stakeholders and around $70 \mathrm{t}$ of PV waste has collected by SENS since 2015 from its various collection points. SENS has now setup a separate collection system at their operation / location points and maintained all the essential processes which are important to handle for a specific kind of e-waste. It has been reported that, nearly 80 to $90 \%$ of the crystalline Si material can be recovered from PV module waste for production of new PV module. There is non-Si PV technology which contains harmful materials are manually separated and handled accordingly, to avoid the possibility of toxic materials escaping into the environment [18].

\subsection{Norway's regulatory and non-regulatory frameworks}

There is no specific guidelines or regulations for end-of-life PV modules, but it has a long history in regulating WEEE directives. Norway is one of the first countries globally which started implementing WEEE regulation in 1998 and adopted WEEE recovery system in 1999. As Although, Norway is not an EU member state, but it is obliged to implement EU Directives in its national legislation by the EEA (European Economic Area) agreement. Therefore, the Norwegian legislation related to WEEE was modified to comply with the WEEE Directive in June 1, 2006. At that time, a Norwegian environment Agency, called EE-Registeret was established to implement WEEE directive. This agency includes a managerial and a web-based module that provides overview of all imports and exports of EEE and WEEE from all manufactures and importers. The Norwegian WEEE legislation has also been modified and the latest WEEE directive was came into force since August 22, 2013.

The WEEE directive in Norwegian legislation covers the wider scope than in EU. According to WEEE Directive 2002/96/EC, there are ten categories defined however the Norwegian legislation also includes four extra categories comprising WEEE largely from industry and business [19].

The Norwegian WEEE Recovery Infrastructure: The Norwegian Government has provided financial support to 5 companies, Elretur AS, Elsirk AS, ERP Norge AS, RENAS AS, and Eurovironment AS, which are registered and authorized by the Norwegian Environment Agency. These companies are directly or indirectly involved to deal with electrical and electronic waste since long time. For example, Elretur and RENAS, are nonprofit organizations owned by the Electric and Electronic Industry and Business Sector and they have been involved in the business for more than 10 years. Elretur has focused on WEEE from households and RENAS on WEEE from industry[19]. It is main responsibility of these companies to ensure free collection of waste from enterprises, suppliers, and municipalities. The collected WEEE is treated pursuant to the guidelines specified by the Norwegian waste regulation.

Further, WEEE waste collection and receipt should be in line with the geographical areas of Norway where member EEE companies are situated, or where they have earlier sold or supplied EEE. In addition, the part of the total collected WEEE must be in line the members' share of the total supply of goods. Currently, more than 4800 organizations have joined the collectively financed take-back companies while there are no individually funded take-back companies in Norway [19]. The very interesting things in the Norwegian WEEE system, are the WEEE collection is organized on a municipal level by intermunicipal waste companies or by stores. The Norwegian WEEE treatment practices follows the outline of Finnish and Swedish practices to attain high material recovery rates and to fulfil the requirements of special treatment of hazardous substances. The Norwegian WEEE treatment practices need to consider the PV 
module waste and its recycling plants for recovering the materials.

\subsection{Czech Republic 's regulatory and non-regulatory frameworks}

In 1 January 2013, Czech Republic introduced the EU WEEE Directive into its own national legislation, by passing the Act no. 165/2012. This directive defines a responsibility of operators of PV power plants to provide finance the control and management of waste from PV modules. The Act imposes the responsibility on operators of PV power plants for PV modules entered into the market before 1 January 2013. The responsibilities include to provide financing for collection, separation, processing, reuse and disposal of electrical waste from PV modules. Therefore, it was mandatory for all operators to register by mid-2013, with collective systems, which took over the responsibility for ensuring proper handling of waste from PV modules for the operators of PV installations as of 1 January 2014 [20]. It has been specifically mentioned in the Directive 2012/19/EU that at least $70 \%$ of the material must be recycled and $80 \%$ must be reused, which results only $20 \%$ of the material can be landfilled [20].

In the Czech Republic, PV Cycle, a European company responsible for WEEE-compliant PV module take-back and recycling, and Retina, a PV module waste processor, have come into a joint venture for the retrieval and recycling of waste PV module. The main advantage of the PV cycles that it offers collective and tailor-made waste management and legal compliance services for different companies and waste processors throughout the world. Although manufacturers and importers of electrical and electronic equipment (EEE and PV module) and batteries do not sell waste products, but legislators ask them to follow the exhaustive waste management requirements. Once the product acquires the EU market then manufacturer is in control of take-back, handling, financing and declaration of their merchandise. Here PV CYCLE empowers those companies to fulfil with their legal obligations - in a simple and costefficient means.

\subsection{Japan's Regulatory and non-regulatory frameworks}

In Japan, Ministry of Economy, Trade and Industry (METI) and Ministry of Environment (MOE) have jointly worked to address issues related to end-of-life of renewable energy equipment such as PV module, solar water heaters and wind turbines. In the mid of 2015, a roadmap was developed for introducing the scheme for collection, handing, recycling and treatment of such merchandise [21]. Based on the roadmap the primary guidelines were launched in April 2016 which incorporates dismantling, transportation, handling, treatment and appropriate way of recycling. It is anticipated that the roadmap and therefore the guideline can take this initiative to more thought of policies regarding the endof-life management of PV module waste [22].

In 2017, the Japan Photovoltaic Energy Association (JPEA) has issued voluntary guidelines on how to appropriately dispose of end-of-life PV modules. JPEA observed that installations of solar have risen gradually in Japan since 2012, and the country has repeatedly appeared in the top three markets globally for PV deployment [23]. As the huge number of end-of-life modules expected in coming years, the committee decided to study in advance how to efficient handling and disposal of these PV module will be organized.

Indeed, the National Institute of Advanced Industrial Science and Technology (NEDO) is already working to develop recycling technology for RE application. A study conducted by the Ministry of Public Management, Home Affairs, Posts and Telecommunications, officially released in September 2017, that several native governments, waste disposers and industrial waste disposal corporations are line of work for additional info on the way to properly disposal of PV modules. Manufacturers, importers, and suppliers of PV modules have also been called on provide prior information on contained chemical materials, to communicate waste disposal companies such as removal contractors. JPEA stated the rules which have no "enforceability", but it is strongly suggested that the trade make use of them [24].

Compare to EU's WEEE directive and its implementation, Japan is still in the process of developing and setting up guidelines for safe and efficient of PV recycling. However, Japan is progressing well in developing and testing technology for PV recycling which can one of the benefits for Japan in coming 
years when significant amount of PV waste will be collected.

\subsection{United State of America (USA)'s regulatory and non-regulatory framework}

There are no specific laws or regulations presently followed within the U.S.A. for the collection gathering, handling and use of end of-life PV modules so the country's general waste laws apply. But there are some states such as like California, Washington those have started operating to develop their own regulation and law for PV module utilization and recycling.

In has been report in ref [25] that California is in the process of developing a regulation for the management of end-of-life PV modules among its borders, however many steps are required to be followed before this regulation is enforced. In California's 2014- 2015 legislative session, Senate Bill 489 was presented, that enables the California Department of Toxic Elements Control to alter the classification of end-of-life PV modules identified as hazardous waste to universal waste. The bill is currently now law in California and a public notice on rulemaking was scheduled in fall 2017 that the rule will become effective within one year.

In July 2017, the Washington state passed Senate Bill 5939, that modifies state renewable energy system tax incentives and requires a takeback and recycling program for end-of-life PV modules [26]. The law emphasizes the PV module makers for introducing the product plans that describe how they'll give financial backing to the employment program at different locations in that state. This plan describes that a manufacturer may join in a national program if its purpose meets the objective of the state program. It also specified the requirement that manufacturers who willing to introduce their PV modules in the state of Washington after July 1, 2017, are accountable to provide financing to the recycling program for their units. PV module producers who do not provide their recycling plan details will not allow sell solar modules after January 1, 2021 [26]. There are several voluntary collection organizations for end-of-life PV modules, as an example, the company First Solar functions commercialscale recycling facilities in Ohio for its own thin-film cadmium telluride (CdTe) PV modules, additionally in Germany and Malaysia.

The U.S. solar power Industries Association (SEIA) has maintained a corporate social responsibility (C.S.R.) committee that reviews progress associated with PV exercise and declared the launch of a National PV exercise Program in Sept 2016 [27]. With the assistance of this programme, SEIA and its members organization are creating the easier way for customers to pick a cost-effective and environmentally friendly end-of-life management solution for their PV modules.

To create awareness and promote PV recycling among different stakeholders SEIA's PV Recycling Working Group can select the most preferred recycling partners who can offer specific advantages solely to SEIA members. However, their standard services will be available to all interested companies. Outline of SEIA's National PV recycling programme has given in ref [27].

Further, SEIA is planning to develop a proactive waste management strategy to avoid landfilling by industries. This strategy includes the national recycling network programme, which will provide a platform to the system owners and customers to know about the recycle their PV modules responsibly. This concept will certainly lead to increase invest in research and development leading to better recycling technologies and best practices. With the goal of making a long-run international circular economy, SEIA is additionally reaching to invest the price savings from effective waste management into analysis and development for clean energy technologies.

\subsection{China's regulatory and non-regulatory frameworks}

At present, however, PV panels are not included the waste electrical and electronic products processing directory of the regulation. The National High-tech R\&D Programme for PV Recycling and Safety Disposal Research has provided recommendations for developing policy guidelines to address PV waste challenges [28].

In February 2009, the State Council of China disseminated the Waste Electrical and Electronic Product Recycling Management Regulation which came into force in January 2011 (State Council of the People's 
Republic of China, 2011). The 2011 regulation become mandatory that e-waste to be collected in different ways and recycled in a centralised processing system. Manufactures can collect and recycle the products by themselves or entrust collection to the venders, after-sales service companies or e-waste recyclers and entrust recycling/ disposal to qualified institutions.

On the policy side, the recommendations include the need for special rules and regulations for end-oflife PV panel recycling, targets for recycling rates and the developing necessary financial frameworks. Whereas, technology and R\&D side, recommendations focused on developing and demonstrating highefficiency, low-cost and low-energy-consumption recycling technologies and processes for crystalline $\mathrm{Si}$ module and thin-film PV modules. In the $13^{\text {th }}, 5$-Year Plan for 2016-2020, directions for accelerating the end-of-life management of waste PV modules are described [29].

\subsection{Korea's regulatory and non-regulatory frameworks}

There are no specific guidelines or regulations governing the end-of-life management of waste PV modules in Korea. However, the report of "2015 energy information and policy support projects" from Ministry of Trade, Industry and Energy (MOTIE) presented a proposal for additional guidelines mandating to report PV waste disposal under "Act on the Promotion of the Development, Use and Diffusion of New and Renewable Energy" as a measure to increase PV recycling [30]. According to the report [30], it would be economical to amend rules covering PV waste to the present law on renewable energy instead of produce a brand new guideline for PV module waste. The report also suggested that a public establishment ought to be elite to handle the procedures associated with coverage of PV module waste disposal, as presently there isn't any establishments responsible of reporting this information.

There are two new projects for PV module recycling were funded in 2016 focused on research, development and demonstration of recycling facility with a capacity of 2 tons per day. The project also targets to reclaim unbroken wafers from PV waste modules with a yield of $<70 \%$ reduce the electricity. The other project is non-R\&D for the formation of a PV recycling center in Korea for the management of PV waste modules [21]. It might take five years to achieve the five missions planned for this recycling center. A part of the recycling technologies developed through the R\&D project will be used for the non$R \& D$ project to enhance the capacity of the recycling center.

\subsection{India's regulatory and non-regulatory frameworks}

India falls on the same category and has no regulations on PV system components collection, recovery and recycling of end-of-life PV module. At present, PV modules generated waste are treated under general waste regulations. Any policy related to waste is developed by the Ministry of Environment, Forest and Climate Change under the 2016 Solid Waste Management Rules and the Hazardous and Other Wastes (Management and Transboundary Movement) Rules (Ministry of Environment, Forest and Climate Change, 2016a and 2016b). Recently, amended Hazardous Waste Rules also include use of Toxicity Characteristic Leaching Procedure and it requires authorisation from the State Pollution Control Board under certain conditions. The Legislation is covered the requirements for general e-waste and restrictions on the use of hazardous substances in electronic equipment are included in the E-waste (Management and Handling) Rules of 2016. However, these rules have limited scope and only apply to household electronics products, not on the PV modules.

\section{Existing Photovoltaic Recycling Initiatives}

Besides country specific directives, there are some initiatives and programmes on PV recycling from different PV manufactures and association. Most these initiatives are voluntarily developed with objective to safe and efficient recycling of PV. This section is focused on three main recycling initiatives that have already been voluntarily developed by PV manufacturers that may be generalized to be used as models: First Solar, SolarWorld Global and PV Cycle. 


\subsection{First solar recycling program}

First Solar is an American company that was formed in 1999, launched production of CdTe-based PV commercial products in 2002. It's a leading global provider of comprehensive PV based solar energy solutions with over $17 \mathrm{GW}$ installed in more than 35 countries. They design, manufacture and sell PV solar modules with an advanced thin film semiconductor technology and develop, design, construct, and sell PV power plants that primarily use the solar modules. First Solar have shown some commitment to the environment by ensuring that all stages of the PV manufacturing process, including end-of-life, create low carbon emissions. Consequently, company claim that their carbon footprint is the lowest among available PV technologies, and compares well with wind technologies [32].

First Solar has a long-standing leadership position in PV recycling. The company established the industry's first voluntary global prefunded module recycling program in 2005 and are the only PV manufacturer capable of offering global PV recycling services today. With over a decade of experience in operating high-value PV recycling facilities on a global and industrial scale, its unrivalled in-house recycling expertise and infrastructure enables to continually drive down recycling prices for customers. First Solar's industry-leading recycling services enable PV power plant and module owners to meet their module end-of-life (EOL) obligation simply, cost-effectively and responsibly. Its state-of-the-art recycling facilities are operational in the U.S., Germany and Malaysia, and have a scalable capacity to accommodate high volume recycling as more modules reach the end of their 25+ year life [33].

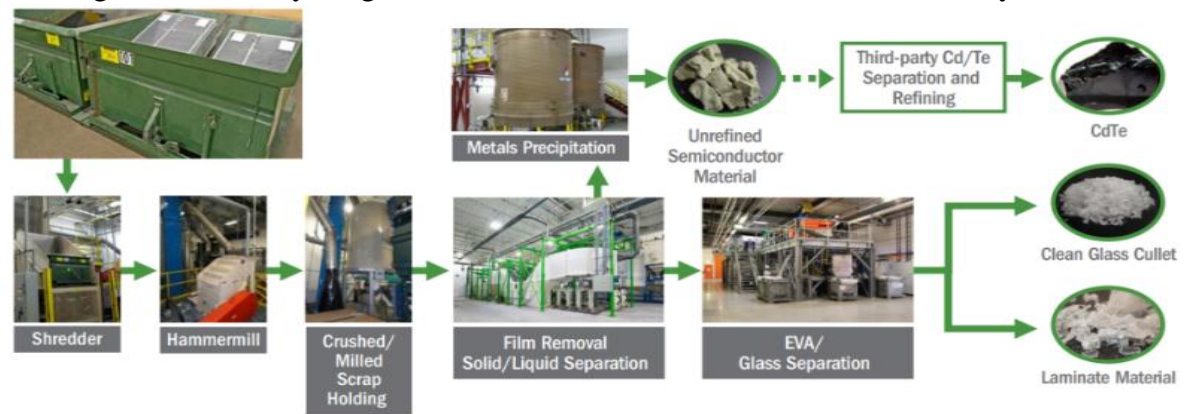

Fig. 2. PV module recycling process at first solar [33]

First solar high-value recycling process recovers approximately 90 percent of the glass for reuse in new glass products and over 90 percent of the semiconductor material for reuse in new modules. During the recycling process, First Solar modules are crushed and shredded to break the lamination bond. The crushed modules are chemically treated to recover semiconductor material from the glass. The unrefined semiconductor material is then sent externally for further processing. Once rinsed and cleaned, the glass is packaged so it can be reused in new glass products. In Malaysia, First Solar laminate material is now being recycled for reuse in rubber mats, bicycle handles, and shoe soles, thereby further closing the loop on product's life cycle. The remainder of the recycled module scrap (approximately 5 to 10 percent) which cannot be used in secondary raw materials is handled using other responsible waste treatment and disposal techniques. Due to the shredding, crushing and heating typically involved in recycling processes, material losses are inevitable, and the recovery ratio is always less than 100\% [34].

\subsection{Solar world AG initiative}

The second example program was developed by SolarWorld AG. SolarWorld Industries GmbH is a German based solar technology company headquartered in Bonn, with production facilities in Arnstadt, Thuringia, Freiberg, and Saxony, and with sales locations in Germany, Singapore and South Africa. SolarWorld is focused exclusively on the production and distribution of premium products based on monocrystalline PERC solar cells, such as bifacial glass-glass modules delivering power generation on both sides, and monofacial PERC modules.

SunWorld's sub-division SolarMaterial, which focuses on many aspects of the PV module life cycle, including the recycling phase. Their program is designed to recycle modules of all designs and sizes that 
have undergone any type of damage (e.g. glass breakage, defective laminate or electrical faults). As a result of this project, and SolarWorld's overall environmental leadership, the company was ranked first overall among crystalline PV manufacturers in a report by the Silicon Valley Toxic Coalition because of their performance on environmental and social responsibilities. Based on this award, clearly one of the benefits for SolarWorld is goodwill. However, because this program includes all types of solar modules, the economic analysis above indicates that it may not be in the benefit of the company to maintain the program in the future $[35,36]$.

\subsection{PV cycle}

PV Cycle is a program that was created by the European PV manufacturing industries. The programme was founded in 2007 to implement the PV industry's commitment to set up a voluntary take back and recycling program [40]. The manufacturers, which make up PV Cycle embrace the concept of producer responsibility and aim to offer a completely sustainable solar energy solution. However, this type of initiative only works if the industry is inclined to voluntarily participate in environmentally responsible manufacturing, which is not yet applicable globally. Without this type of initiative being regulated, manufacturing companies are free to withdraw from the program.

With a total of 15,042 tonnes processed since the start of its operations in 2010 - or 1,803 tonnes in 2016 -PV Cycle continued to retain its world-leading position in the collection and treatment of photovoltaic module waste. While the company recorded a moderate increase in the traditionally highvolume waste markets of Germany, Italy and Spain, its operations rose by more than $60 \%$ in France and Belgium in 2016. At the same time, its membership increased to more than doubled [37].

In February 2016, the Association announced a new record in silicon-based PV module recycling, achieving a $96 \%$ recycling rate. Enabling the recycling of silicon flakes - a combination of laminate, silicon-based semiconductors and metals - in a way which is both economical and environmentally sound, the advanced process is currently being applied at one of PV Cycle's Europe-based recycling partners for silicon-PV.

PV Cycle have reached new partnership agreements with several treatment facilities at the end of 2016. In November 2016, PV Cycle launched a tender for additional treatment partners specifically for the French market. Technological enhancements and innovations are key to their waste treatment operations [38]. As part of the company's efforts to continuously improve and encourage investments in new, innovative waste treatment technologies, PV Cycle is also involved in several R\&D projects.

PV Morede, funded by the 2012 Eco Innovation Programme, researched the development and industrialization of a patented mobile recycling device. Compared with other industrial waste systems, PV Morede can treat PV modules directly where they are installed, thereby offering a cost-effective and easily accessible waste treatment solution for small quantities of PV panels. In a later stage, the project partners are set to work on a commercialization plan for the innovative recycling plant.

CU-PV is a pan-European R\&D project under the European Union's FP7 Programme. With the goal of improving the environmental profile of silicon-based PV modules, the CU-PV partners investigated the reduction of silver and lead in PV, ways to eco-design and high-value end-of-life treatment. Bringing research, production and waste treatment partners to this project, CU-PV covered the entire life cycle of a silicon-based PV module.

\section{Conclusions and Recommendations}

This paper has reviewed the growth of solar PV waste till 2050 and its importance in terms of making the environment sustainable and pollution free. It has been discussed in detail that policies and guidelines following globally for PV recycling and how these best practices can be used in other countries. For example, all the $28 \mathrm{EU}$ member states have taken initiatives for establishing the regime for PV module collection and handling in accordance with WEEE Waste. Based on the cumulative PV waste from PV module installations different countries have developed their own local guidelines and plan to execute the WEEE directive. 
Selected countries policies and regulations on PV recycling have been studied. In case of Germany, two financial mechanism e.g. Business-to-Consumer (B2C) and Business-to-Business (B2B) are studied for implementing the PV module recycling programme. For B2C transaction, the new ElektroG producers will responsible selling their product to the private households and ensure the present and future end-oflife obligations. Whereas, B2B transaction approach provides a different financial model of end-of-life PV obligations for PV producers or PV plant owner based on quantities, capacity size, level of complexity etc. According to the UK WEEE legislation, all PV producers must register under a producer compliance scheme and submit related data on products intended for household (B2C) and non-household (B2B) markets. Similarly, in Italy major PV market players are adapting EU WEEE Directive (2012/29/EU) and becoming Nation Register Member to provide financial support for the transport and recycling of PV across the country. In case of Scandinavian countries, Norwegian Government has taken a different approach for implementing WEEE directive. The collection mechanism is organized on a municipal level by inter-municipal waste companies or by stores and government has also provided financial support to five companies, registered and authorized by the Norwegian Environment Agency. The Norwegian WEEE treatment practices follows the outline of Finnish and Swedish practices to attain high material recovery rates and to fulfil the requirements of special treatment of hazardous substances. In Japan, Ministry of Economy, Trade and Industry (METI) and Ministry of Environment (MOE) have jointly worked to address issues related to end-of-life of renewable energy equipment including PV module. There are counties like USA, China and India where no specific laws related to PV recycling are presently specified. In USA, local government are working to develop the guidelines based on learning and feed-back and states Washington and California have recently passed the Senate Bill for that purpose. It has emphasized that PV module manufacturers should introduce life cycle product plans that describe how they'll give financial backing to the employment program at different locations in that state. In China, the National High-tech R\&D Programme for PV Recycling and Safety Disposal Research has provided recommendations for developing policy guidelines to address PV waste challenges.

There are a lot of learning from the various volunteer / industry initiatives i.e. First Solar, SolarWorld Global and PV Cycle and it is important to consider the learnings from these industry initiatives in developing policy guidelines, regulations, technologies and make them more flexible for adaptation.

It has been critically observed that the development regulatory framework/guidelines and innovative business models, build up capacity of local institutions and PV recycling industry are very important for the PV end-of-life management system. Some of the countries which are early at stage of addressing PV recycling challenges, can use the EU's expertise as well as in coordination with the PV manufacturers for developing regulatory framework and guidelines.

\section{Acknowledgements}

This work is supported by the Norwegian Ministry of Foreign Affairs through the Royal Norwegian Embassy New Delhi (India) under framework agreement with the TERI (India) and University of Agder (Norway) for the project theme 'Sustainability and Clean Energy'.

\section{References}

[1] Garcia CGY and Olvera BAB. The importance of increasing actual INDCs' ambitions to meet the paris agreement temperature targets: An innovative fuzzy logic approach to temperature control and climate assessment using FACTS. In: Proc. of 2016 6th International Conference on Simulation and Modeling Methodologies, Technologies and Applications (SIMULTECH), 2016, pp. 1-5.

[2] Azmi AN and Kolhe ML. Photovoltaic based active generator: Energy control system using stateflow analysis. In: Proc. of 2015 IEEE 11th International Conference on Power Electronics and Drive Systems, 2015, pp. 18-22.

[3] Ihsan Ali GS, Tania U. A preliminary feasibility of roof-mounted solar PV systems in the Maldives. Renewable and Sustainable Energy Reviews, 2018; 83: 18-32.

[4] "IRENA (2018), Renewable Power Generation Costs in 2017," International Renewable Energy Agency, Abu Dhabi, 2018.

[5] Munsell M. 10 Trends That Will Shape the Global Solar Market in 2018, Jan 2018. 
[6] "India second largest solar market on back of 113 GW global installations.," Bridge to India "India Solar Compass" - a quarterly report on the Indian solar market Q4 2017-2018.

[7] Berg J. India second largest solar market on back of 113 GW global installations. April 2018

[8] Baldé CP, et al., The Global E-waste Monitor - 2014: Quantities, Flows and Resources, United Nations University, Institute for the Advanced Study of Sustainability, Bonn, 2015.

[9] "End-of-Life Management: Solar Photovoltaic Panels," International Renewable Energy Agency and International Energy Agency Photovoltaic Power Systems, 2016.

[10] Clercq GD. Europe's first solar panel recycling plant opens in France, June 2015.

[11] Hutchins M. EU funds pilot plant for PV module recycling, Aug 2018.

[12] Xu Y, Li J, Tan Q, Lauren PA, and Yang C, Global Status of Recycling Waste Solar Panels: A Review, 2018.

[13] McDonald NC and Pearce JM. Producer responsibility and recycling solar photovoltaic modules. Energy Policy, 2010; 38(11): 7041-7047.

[14] Cucchiella F, Adamo I. D', Lenny Koh S. C., and Rosa P. Recycling of WEEEs: An economic assessment of present and future e-waste streams. Renewable and Sustainable Energy Reviews, 2015; 51: 263-272, 2015/11/01/.

[15] Smith C. "Inside Italy’s e-waste problem.," 2013.

[16] Khetriwal DS, Kraeuchi P, and Widmer R. Producer responsibility for e-waste management: Key issues for consideration Learning from the Swiss experience. Journal of Environmental Management, 2009; 90(1): 153-165, 2009/01/01/.

[17] Mehta SL, IIIEE Theses IMEN56 20171 The International Institute for Industrial Environmental Economics, 2017.

[18] "SENS/Swico/SLRS Technical report, 2016. ," May 2017.

[19] "European Union- PV CYCLE offers collective and tailor-made waste management and legal compliance services for companies and waste holders in the European Union."

[20] Lenka JM, Zemková, Jiří Louda, Ondřej Vojáček, "Readjusting environmental fees for products with a long lifetime: Case of PV module recycling fee in the Czech republic," The International Scientific Conference INPROFORUM České Budějovice, pp. 256-260, Nov 2015

[21] 2015, "Report on recycling and proper treatment of end-of-life PV and other equipment," Committee on reuse, recycling and proper treatment of end-of-life renewable energy equipment (under METI and MOE, Japan), 2015

[22] "A Guideline of promoting recycling and proper treatment of end-of-life PV equipment, 2016," MOE (Ministry of Environment, Japan), 2016.

[23] Kenning T. Japan issues guidelines on 'proper disposal' of used solar modules, PVTECH Dec 2017.

[24] "Properly dispose of end-of-life solar PV modules," The Japan Photovoltaic Energy Association (JPEA)'s voluntary guidelines, 2017.

[25] "California Legislature, Hazardous Waste: Photovoltaic Modules," Senate Bill No. 489, Chapter 419, an act to add Article 17 (commencing with Section 25259) to Chapter 6.5 of Division 20 of the Health and Safety Code, relating to hazardous waste, approved by the Governor Oct 2015.

[26] "Washington States Legislature, Promoting a sustainable, local renewable energy industry through modifying renewable energy system tax incentives and providing guidance for renewable energy system component recycling," Senate Bill 5939, 2017.

[27] "SEIA (Solar Energy Industry Association, USA), SEIA National PV Recycling Programme.."

[28] Zhang J, Lv F, et al., "Technical route and policy suggestion of PV recycling in China," 2015.

[29] "Research Report on Renewable Energy Technology Innovation Strategy of China," Ministry of Science and Technology of China, 2016.

[30] Kang GH, Lee JS., et al., "Study on an establishment of PV module recycling system," Ministry of Trade, Industry and Energy (MOTIE), 2015.

[31] "A newspaper article (in Korean), Yonhap News Agency," November 14, 2016.

[32] D. Lincot, "Summary report on Environmental, Health, and Safety (EHS) aspects of First Solar cadmium telluride(CdTe) photovoltaic(pv) systems by the French Ministry of Ecology," Energy, Sustainable Development, and the Sea., 2009.

[33] "First Solar Sustainability Report," 2017.

[34] McKinney S, and Yonavjak,, "Mineral resources, environmental science systems and solutions," Jones \& Bartlett Learning," 2013.

[35] Material S, "Module recycling. Accessed 6th December, 2009.," 2009.

[36] Santarris B, "SolarWorld earn stop score among conventional module makers in tech watchdog group's sustainability‘ score card'," March 2010.

[37] D. 2009., "Article on PV Cycle, Making photovoltaics“'DoubleGreen”."

[38] "PV Cycle annual report 2016 - 'Operational and Financial Review'." 